\title{
PERAN KEPEMIMPINAN KEPALA MADRASAH DALAM MENINGKATKAN KINERJA GURU
}

\author{
Abdi Setiawan, Tajudin Noor, Sayan Suryana \\ Universitas Singaperbangsa Karawang \\ Abdisetiawan561@yahoo.com, tajudin.noor@fai.unsika.ac.id, sayan.suryana@fai.unsika.ac.id
}

\begin{abstract}
This study aims to analyze and illustrate the leadership role of the madrasa head in improving teacher performance in MIS Asy Syarifiyah, Cikampek District, Karawang Regency. The study uses descriptive qualitative research methods. Data collection is done by using methods a) observation, b) interviews and c) documentation. Based on the results of the study it can be concluded that the headmaster of the madrasa uses a democratic leadership style and has performed its role as a madrasa leader in improving teacher performance by making plans and implementation through coaching and development. So that between leadership and planning styles as well as the implementation of the headmaster has a causal relationship or cause and effect that makes the teacher as a professional educator to realize the objectives of the madrasah better.
\end{abstract}

Keywords: Role of Leadership, Teacher Performance.

\begin{abstract}
Abstrak
Penelitian ini bertujuan untuk menganalisis dan menggambarkan peran kepemimpinan kepala madrasah dalam meningkatkan kinerja guru di MIS Asy Syarifiyah Kecamatan cikampek Kabupaten Karawang. Penelitian menggunakan metode penelitian deskriptif kualitatif. Pengumpulan data dilakukan dengan menggunakan metode a) observasi, b) wawancara dan c) dokumentasi. Berdasarkan hasil penelitian dapat disimpulkan bahwa kepala madrasah menggunakan gaya kepemimpinan demokratis dan telah melakukan perannya sebagai pemimpin madrasah dalam meningkatkan kinerja guru dengan membuat perencanaan dan pelaksanaan melalui pembinaan dan pengembangan. Sehingga anatara gaya kepemimpinan dan perancanaan maupun pelaksanaan kepala madrasah memiliki hubungan kausal atau sebab akibat yang menjadikan guru sebagai pendidik profesional untuk mewujudkan tujuan madrasah yang lebih baik.
\end{abstract}

Kata Kunci:Peran Kepemimpinan, Kinerja Guru. 


\section{A. PENDAHULUAN}

Kepala sekolah/madrasah sebagai pemimpin pendidikan hendaknya berperilaku membangun, karena keberhasilannya sangat tergantung pada kualitas kepemimpinannya dalam hal meningkatkan kinerja guru. Pentingnya kepemimpinan kepala sekolah/madrasah dalam kaitannya dengan desentralisasi pendidikan yang menekankan manajemen berbasis pendidikan kepala madrasah memiliki otonomi yang tinggi dalam memajukan dan mengembangkan sekolahnya (Mulyasa, 2019:18).

Pendidikan dan pengalaman yang dimiliki oleh kepala madrasah merupakan faktor yang mempengaruhi kepemimpinannya, di samping itu pemberian wewenang terhadap tanggung jawab dalam pengawasan di madrasah, kesadaran terhadap fungsinya sebagai pemimpin pendidikan serta waktu yang dapat dipakai oleh kepala madrasah untuk menjalankan fungsi supervisi merupakan faktor-faktor yang sangat mempengaruhi kesempatan kepala madrasah untuk mengembangkan kepemimpinannya. Kepala madrasah sebagai penanggungjawab pendidikan pada tingkat sekolah memiliki kewenangan dan keleluasaan dalam mengembangkan program, mengelola, serta pengawasan yang ada di madrasah.

Memiliki keleluasaan dalam mengelola segenap sumber daya yang dimiliki kepala madrasah agar terjadi peningkatan mutu dan produktivitas yang signifikan dalam memberikan layanan belajar bermutu untuk pengembangan peserta didik. Menurut Pamudji, S. (1985:7) bahwa: Pembinaan berasal dari kata "bina"yang berarti sama dengan "bangun", jadi pembinaan dapat diartikan sebagai kegunaan yaitu: merubah sesuatu sehingga menjadi baru yang memiliki nilai-nilai yang tinggi. Dengan demikian pembinaan juga mengandung makna sebagai pembaharuan, yaitu: melakukan usaha-usaha untuk membuat sesuatu menjadi lebih sesuai atau cocok dengan kebutuhan dan menjadi lebih baik dan lebih bermanfaat. Pemimpin harus memberikan pembinaan kepada anggotanya agar dapat berkerja secara berdaya guna dan berhasil guna, sehingga pekerjaan yang dihasilkan mempunyai kualitas. Adanya pembinaan disiplin kerja oleh kepala madrasah terhadap tenaga pendidik, maka diharapkan tujuan-tujuan yang sudah direncanakan dapat berjalan dengan baik.

Kinerja guru adalah kegiatan guru dalam proses pembelajaran yaitu bagaimana seorang guru merencanakan pembelajaran, melaksanakan kegiatan pembelajaran, dan menilai hasil belajar. Berdasarkan pengertian di atas dapat diketahui bahwa kinerja guru merupakan keseluruhan perilaku guru dalam mencapai tujuan terhadap pelaksanaan tugas yang dibebankan kepadanya baik sebgai pengajar, pelatih, pembimbing serta kegiatan yang dilakukan oleh seorang guru dalam rangka menyusun perencanaan pembelajaran, melaksanakan proses pembelajaran, menilai pembelajaran siswa serta pengembangan peserta didik untuk mengaktualisasikan berbagai potensi yang dimilikinya.

Maka dari itu Peranan kepemimpinan kepala sekolah/madrasah menurut Mulyasa (2019:18) sangatlah penting dalam meningkatkan kinerja guru. Pada madrasah memiliki permasalahan dalam kinerja guru yang belum maksimal seperti kelalaian guru dalam kedisiplinan. Oleh karena itu, kepala madrasah mempunyai tanggung jawab besar dalam organisasi pendidikan dan untuk memimpin organisasinya agar bisa berjalan dengan baik. Kriteria kepala madrasah secara efektif dalam hal ini adalah mampu memberdayakan pendidik atau guru untuk mewujudkan proses pembelajaran yang berkualitas, lancar dan produktif. Menurut Mulyasa (2019:63) Pengembangan guru harus dilakukan kepala sekolah/madrasah dalam manajemen pendidikan, yang bertujuan untuk memberdayagunakan guru secara efektif dan efesien untuk mencapai hasil yang optimal. Kepala madrasah yang menarik, mengembangkan, menggaji dan memotivasi guru untuk mencapai tujuan pendidikan, membantu guru mencapai posisi standar perilaku, memaksimalkan perkembangan karier guru, serta dapat menyelaraskan tujuan individu dan organisasi madrasah.

Kepemimpinan menurut Imam Machali dan Ara Hidayat (2016:84) adalah kemampuan untuk menggerakan, memengaruhi, memotivasi, mengajak, mengarahkan, menasihati, membina dan bahkan memberikan penghargaan maupun hukuman dengan maksud agar seseorang mau bekerja dalam rangka mencapai tujuan dirinya sendiri maupun organisasi secara efektif dan efisien.

Diperkuat dengan pendapat Ahmad Susanto (2016:8) gaya kepemimpinan adalah suatu cara yang digunakan pemimpin dalam berinteraksi dengan bawahannya, pada umumnya dikenal ada lima gaya kepemimpinan. Kelima gaya kepemimpinan tersebut yang dapat digunakan seorang pemimpin untuk memengaruhi perilaku orang lain adalah :

a) Gaya Kepemimpinan Otokratis, kepemimpinan otokratis disebut juga kepemimpinan dictator atau direktif. Orang yang menganut pendekatan ini mengambil keputusan tanpa berkonsultasi dengan para bawahannya yang harus melaksanakannya 
atau seseorang yang akan dipengaruhi keputusan tersebut. Mereka menentukan apa yang harus dilakukan orang lain dan mengharapkan mereka mematuhinya. Satu keuntungan dari kepemimpinan otokratis ini adalah kecepatan dalam membuat keputusan. Pemimpin tidak harus memperoleh persetujuan para anggota kelompok sebelum memutuskan. Adapun kekurangan dalam kepemimpinan ini adalah berpengaruh pada semangat kelompok. Para anggota makin merasa tidak senang dengan cara putusanputusan itu dibuat dan karenanya mendukung putusan-putusan itu hanya sekadarnya saja. Orientasi kepemimpinan otokratis ini difokuskan hanya untuk peningkatan produktivitas kerja bawahan dengan kurang memperhatikan perasaan dan kesejahteraan bawahan. Pimpinan menganut sistem manajemen tertutup kurang menginformasikan keadaan organisasi kepada bawahannya, pengkaderan kurang mendapat perhatian dari pemimpin.

b) Gaya Kepemimpinan Demokratis, kepemimpinan demokratis mempertimbangkan keinginan dan ide-ide para bawahannya. Ini adalah pendekatan hubungan manusia dalam semua anggota kelompok dilihat sebagai penyumbang penting kepada keputusan akhir. Gaya kepemimpinan ini dikenal pula dengan istilah kepemimpinan konsultatif atau consensus. Orang yang menganut pendekatan ini melibatkan para bawahannya yang harus melaksanakan keputusan dalam proses pembuatannya, walaupun yang membuat keputusan akhir adalah pemimpin, tetapi hanya setelah menerima masukan dan rekomendasi dari bawahan. Kritik terhadap pendekatan ini menyatakan bahwa keputusan yang paling baik tidak selalu menerapkan keputusan terbaik, dan bahwa kepemimpinan demokratis sesuai dengan sifatnya, cendrung menghasilkan keputusan yang paling tepat.

c) Gaya Kepemimpinan Partisipatif, kepemimpinan partisipatif juga dikenal dengan istilahkepemimpinan terbuka dan bebas. Orang yang menganut pendekatan ini hanya sedikit memegang kendali dalam proses pengambilan keputusan. Ini hanya menyajikan informasi mengenai suatu permasalahan dan memberikan kesempatan kepada bawahannya untuk mengembangkan suatu strategi dan pemecahannya. Tugas pemimpin adalah mengarahkan anggota kepada tercapainya consensus. Asumsi yang mendasari gaya kepemimpinan ini adalah bahwa para bawahan akan lebih siap menerima tanggung jawab terhadap solusi, tujuan, dan strategi di mana mereka diberdayakan untuk mengembangkannya. Kekurangan dalam kepemimpinan ini adalah bahwa dengan pembentukan consensus banyak membuang waktu dan hanya akan berjalan bila semua orang yang terlibat memilki komitmen terhadap kepentingan utama suatu lembaga. Kepemimpinan partisipatif ini dalam kepemimpinannya dilakukan dengan persuasive, menciptakan kerja sama yang serasi, menumbuhkan loyalitas dan partisipasi bawahan. Pemimpin memotivasi bawahan agar mereka ikut memiliki organisasi. Pemimpin dengan gaya partisipatif ini akan mendorong pimpinan akan selalu membina bawahan untuk menerima tanggung jawab yang lebih besar.

d) Gaya Kepemimpinan Berorientasi, gaya kepemimpinan ini juga disebut kepemimpinan berdasarkan hasil dan berdasarkan sasaran. Orang yang menganut pendekatan ini meminta agar para bawahan atau anggota untuk memusatkan perhatiannya hanya pada tujuan yang ada. Hanya strategi yang dapat menghasilkan kontribusi nyata dan dapat diukurdalam mencapai tujuan organisasi yang di bawah, pengaruh kepribadian dan faktor lainnya yang tidak berhubungan dengan tujuan organisasi diminimumkan. Kekurangan yang ada dalam gaya ini adalah pemimpin cenderung memiliki fokus yang terlampau sempit dan sering kali berfokus pada perhatian yang keliru.

e) Gaya Kepemimpinan Situasional, gaya kepemimpinan situasional mengacu pada pendekatan teori situasional yang menekankan perilaku pemimpin dan model praktis yang dapat digunakan pemimpin untuk membuat keputusan dari waktu ke waktu secara efektif dalam rangka memengaruhi perilaku orang lain. Gaya kepemimpinan ini dikenal juga sebagai kepemimpinan tak tetap atau kontingensi. Asumsi yang digunakan dalam gaya ini adalah bahwa tidak ada satupun gaya kepemimpinan yang tepat bagi seorang pemimpin dalam segala kondisi. Oleh karena itu, gaya kepemimpinan situasional akan menerapkan suatu gaya tertentu berdasarkan pertimbangan atas faktor-faktor seperti memimpin, pengikut, dan situasi dalam arti stuktur tugas dan dinamika kelompok.

Menurut Imam Machali dan Ara Hidayat (2016:108) kepala madrasah dalam satuan pendidikan merupakan pemimpin. Ia mempunyai dua jabatan dan peran penting dalam melaksanakan proses pendidikan. Pertama, kepala madrasah adalah pengelola pendidikan di madrasah dan kedua kepala madrasah adalah pemimpin formal pendidikan di madrasahnya. Sebagai pengelola pendidikan, kepala madrasah 
bertanggung jawab terhadap keberhasilan penyelenggaraan kegiatan pendidikan dengan cara melaksanakan administrasi madrasah dengan seluruh substansinya. Di samping itu, kepala madrasah bertanggung jawab terhadap kualitas sumber daya manusia yang ada agar mereka mampu menjalankan tugas-tugas pendidikan. Oleh karena itu, sebagai pengelola, kepala madrasah memiliki tugas untuk mengembangkan kinerja para personal (terutama guru) kearah profesionalisme yang diharapkan.

Pemberian motivasi terhadap guru, dalam kaitan ini kepala madrasah dituntut untuk memilki kemampuan memotivasi guru agar mereka mau dan mampu mengembangkan dirinya secara optimal. Hal ini terutama dalam kegiatan-kegiatan yang berkaitan langsung dengan kinerja guru. Penghargaan yang diberikan kepala madrasah sangat penting untuk meningkatkan kinerja guru dan untuk mengurangi kegiatan yang kurang produktif. Melalui penghargaan ini guru dirangsang untuk meningkatkan kinerja yang positif dan produktif. Penghargaan ini akan bermakna apabila dikaitkan dengan prestasi guru secara terbuka, sehingga setiap guru memilki peluang untuk meraihnya. Penghargaan ini perlu dilakukan secara tepat, efektif, dan efisien, agar tidak menimbulkan dampak. Dan yang terakhir adalah persepsi, persepsi adalah proses seseorang mengetahui beberapa hal melalui pancaindra. Sedangkan Sarlito (1982:76) mengartikan persepsi sebagai daya mengenal objek, mengelompokan, membedakan, memusatkan perhatian, mengetahui dan mengartikan melalui pancaindra. Persepsi yang baik akan menumbuhkan iklim kerja yang kondusif serta sekaligus akan meningkatkan kinerja guru. Kepala madrasah perlu menciptakaan persepsi yang baik bagi setiap guru terhadap kepemimpinan kepala madrasah, agar mereka dapat meningkatkan kinerjanya.

Dalam meningkatkan kinerja guru, menurut Mulyasa (2019:64) perlu adanya pengembangan yang dilakukan kepala madrasah mencakup:

\section{- Perencanaan}

Perencanaan tenaga kependidikan merupakan kegiatan untuk menentukan kebutuhan guru. Penyusunan rencana manajemen yang baik dan tepat memerlukan informasi yang lengkap dan jelas tentang pekerjaan atau tugas yang harus dilakukan guru . Karena itu, sebelum menyusun rencana, perlu dilakukan analisis pekerjaan dan analisis jabatan untuk memperoleh deskripsi pekerjaan.

- Pelaksanaan
Madrasah senantiasa menginginkan agar guru melaksanakan tugas secara optimal dan melaksanakan segenap kemampuannya untuk kepentingan madrasah, serta bekerja lebih baik dari hari ke hari, sehingga terjadi perbaikan yang berkesinambungan. Di samping itu, guru membutuhkan peningkatan dan perbaikan pada dirinya termasuk dalam tugasnya. Sehubungan itu, pembinaan dan pengembangan guru merupakan fungsi manajemen pendidikan yang mutlak perlu, untuk memperbaiki, menjaga dan meningkatkan kinerja. Kegiatan ini dapat dilakukan dengan cara penataran atau seminar guru yang diberikan langsung oleh lembaga pendidikan maupun oleh kepala madrasah.

Upaya yang dapat dilakukan untuk meningkatkan kinerja guru madrasah, kepala madrasah harus mampu menumbuhkan disiplin guru. Dilengkapi dengan pendapat Mulyasa (2018:141) dalam menumbuhkan disiplin guru, kepala madrasah harus mampu melakukan hal-hal sebagai berikut:

- Membantu guru mengembangkan pola perilakunya;

- Membantu guru meningkatkan standar perilakunya;

- Menggunakan pelaksanaan aturan.

Lebih lanjut dikemukakan pentingnya disiplin untuk menanamkan:

- Respect for authority (rasa hormat terhadap kewenangan);

- Co-operative effort (upaya untuk menanamkan kerjasama);

- The need for organization (kebutuhan untuk organisasi);

- Respect for others (rasa hormat terhadap orang lain).

Dalam pembinaan dan pengembangan kepala madrasah perlu melakukan program Reward (penghargaan) dan punishment (hukuman) dalam meningktakan kinerja guru menurut Rendra Maulana Suryadilaga, Mochammad Al Musadieq dan Gunawan Eko Nurtjahjono (2016:39), Reward (penghargaan) merupakan balas jasa yang diberikan lembaga kepada anggotanya atas dasar pengorbanan waktu, tenaga dan pikiran. Yang memilki tujuan dari program Reward (penghargaan) adalah:

- Menarik orang yang memiliki keahlian;

- Mempertahankan seseorang agar terus bekerja;

- Memotivasi seseorang untuk mencapai kinerja yang tinggi. 
Menurut Mulyasa (2018:138) Standar kinerja merupakan tolak ukur dalam mengadakan perbandingan antara apa yang telah dilakukan dengan yang diharapkan. Kaitannya dengan pekerjaan khususnya guru yang telah dipercayakan kepada masyarakat untuk mendidik sekaligus membina peserta didik. Standard dapat pula dijadikan ukuran dalam mengadakan pertanggungjawaban terhadap sesuatu yang telah dilakukan. Sejalan dengan itu, Mitchell (1978:343) menyatakan bahwa kinerja meliputi beberapa aspek, yaitu kualitas, kecepatan, inisiatif, kemampuan dan komunikasi dalam bekerja. Kelima aspek tersebut dapat dijadikan ukuran dalam mengkaji kinerja guru.

Indikator dalam menentukan kinerja guru yang tinggi dapat dicapai dengan pengembangan guru. Dilengkapi pendapat Mulyasa (2019:63) pengembangan guru merupakan pekerjaan yang harus dilakukan kepala madrsah dalam manajemen pendidikan, yang bertujuan untuk mendayagunakan guru secara efektif dan efisien untuk mencapai hasil yang optimal. Manajemen pendidikan yang harus dilaksanakan kepala madrasah adalah menarik, mengembangkan, menggaji, dan memotivasi guru untuk mencapai tujuan madrasah, membantu guru mencapai posisi dan standard perilaku, memaksimalkan perkembangan karier guru, serta menyelaraskan tujuan guru dengan organisasi madrasah. Semua itu perlu dilakukan dengan baik dan benar agar apa yang diharapkan tercapai, yakni tersedianya guru yang diperlukan dengan kualifikasi dan kemampuan yang sesuai serta dapat melaksanakan pekerjaan dengan baik dan berkualitas.

Memperkuat pendapat diatas Mulyasa (2019:67) mengemukakan bahwa pengembangan guru perlu dilakukan pada setiap madrasah untuk memastikan bahwa mereka tetap dapat mempertahankan kualitas profesionalitasnya sesuai dengan kebutuhan madrasah. Program pengembangan tersebut memberi penekanan pada pembentukan professional mereka guna meningkatkan kinerja guru di madrasah.

Pembentukan Profesionalitas dalam meningkatkan kinerja guru tercantum dalam standar kompetensi inti guru professional sebagaimana diatur dalam Permendiknas Nomor 16 Tahun 2007, yaitu :

- Menguasai materi, stuktur, konsep dan pola pikir keilmuan yang mendukung mata pelajaran yang diampu dan menguasai 5tandard kompetensi atau kompetensi dasar mata pelajaran yang diampu;
- Dapat mengembangkan materi pembelajaran yang diampu secara kreatif;

- Mengembangkan keprofesionalan secara berkelanjutan;

- Memanfaatkan teknologi informasi dan komunikasi untuk mengembangkan diri (Imam Machali dan Ara Hidayat, 2016:333).

\section{B. METODE PENELITIAN}

Penelitian ini menggunakan metode kualitatif deskriptif. Penelitian ini memberikan gambaran dan mendeskripsikan secara objektif, faktual dan medalam mengenai peran kepemimpinan kepala madrasah dalam meningkatkan kinerja guru di MIS Asy Syarifiyah Kecamatan Cikampek Kabupaten Karawang. Jenis data yang dikumpulkan dalam penitian ini adalah data kualitatif. Data kualitatif adalah katakata dan tindakan selebihnya adalah data tambahan seperti dokumen dan lain-lain mengenai peran kepemimpinan kepala madrasah dalam meningkatkan kinerja guru di MIS Asy Syarifiyah Kecamatan Cikampek Kabupaten Karawang. Data ini bersumber dari orang yang diamati, diwawancarai, dan dicatat melalui catatan tertulis atau pengambilan foto. Untuk mendapatkan data tersebut peneliti mewawancarai Kepala MIS Asy Syarifiyah Kecamatan Cikampek Kabupaten Karawang, tenaga pendidik dan kependidikan, dan peserta didik.Penelitian ini akan dilaksanakan di MIS Asy Syarifiyah Kecamatan Cikampek Kabupaten Karawang, yang bertempat di Dusun Babakan Sereh 03/03 Dawuan Barat Kecamatan Cikampek Kabupaten Karawang, 41373. Teknik yang dipakai dalam pengumpulan data: a) Observasi, Peneliti melakukan pengumpulan data dengan cara observasi atau pengamatan di MIS Asy Syarifiyah Kecamatan Cikampek Kabupaten Karawang. Dengan observasi ini peneliti dapat melihat hal-hal yang kurang atau tidak diamati orang lain, dapat menemukan hal-hal yang luar responden, sehingga peneliti memperoleh gambaran yang lebih kompherensif. b) Wawancara, Peneliti telah menyiapkan pertanyaan kepada kepala madrasah MIS Asy Syarifiyah Kecamatan Cikampek Kabupaten Karawang, berkenaan mengenai peran kepemimpinan madrasah dalam meningkatkan kinerja guru. Serta pertanyaan kepada perwakilan guru untuk memperkuat pernyataan dari hasil wawancara kepala madrasah. c) Dokumentasi, Dokumentasi yang dilakukan peneliti yaitu berupa foto observasi dan wawancara di MIS Asy Syarifiyah Kecamatan Cikampek Kabupaten Karawang. Agar menjaga keaslian dan keabsahan dari penelitian yang sedang dilakukan oleh peneliti.

\section{HASIL DAN PEMBAHASAN \\ 1. Gaya kepemimpinan Madrasah}


Berdasarkan hasil penelitian tentang peran kepemimpinan kepala madrasah dalam meningkatkan kinerja guru di MIS Asy Syarifiyah Kecamatan Cikampek Kabupaten Karawang, baik melalui wawancara dan observasi. Maka peneliti simpulkan Peran Kepemimpinan Kepala Madrasah Dalam Meningkatkan kinerja menggunakan gaya kepemimpinan demokratis. Hal tersebut diperkuat oleh wawancara dengan Bapak H. Edeng Suapi, M.Pd.I, selaku kepala madrasah dalam peraturan kedisiplinan waktu untuk menghindari kelalaian guru contohnya telat datang ke madrasah. Jika guru lalai akan dikenakan denda lima ribu rupiah perhari dan jika ada guru yang memiliki mentaati peraturan maka ada penambahan gaji dan itu atas masukan dan persetujuan bersama dengan guru dan tenaga kependidikan.

Berdasarkan hasil wawancara dan observasi menunjukan bahwa kepala MIS Asy Syarifiyah Kecamatan Cikampek Kabupaten Karawang yang membuat keputusan keputusan akhir setelah menerima masukan dan rekomendasi dari guru bahwa harus ada pemberlakuan reward (penghargaan) dan punishment (hukuman) bagi guru yang taat dan lalai dalam bertugas. Karena kondisi pada saat itu ada salah satu guru yang melakukan kelalaian sehingga menghambat pembelajaran di kelas. Dan akhirnya pemberlakuan reward (penghargaan) dan punishment (hukuman) telah disetujui dengan keputusan bersama antara kepala madrasah, guru maupun tenaga kependidikan.

\section{Perencanaan dan Pelaksanaan kepala madrasah}

Kepala madrasah membuat perencanaan sesuai dengan kebutuhan yang diperlukan madrasah saat itu. Hal tersebut diperkuat oleh wawancara dengan bapak H. Edeng Suapi, M.Pd.I, bahwa ada perencanaan program yang rutin dilakukan ada rapat guru dan staff dengan kepala madrasah setiap bulan untuk dilakukan evaluasi kerja. Ada juga program tingkat kecamatan dan kabupaten binaan pengawas Madrasah Ibtidaiyah dari Kementerian Agama yang diadakan tiap bulan. Dan rencana kedepan madrasah standar pembinaan dari Erlangga untuk meningkatkan kinerja guru, kedisiplinan guru, lalu pemberlakuan reward dan punishment.

Sedangkan pelaksanaan program madrasah yaitu menunjukan bahwa kepala madrasah mampu meningkatkan kinerja guru bukan hanya dalam perencanaan saja. Melainkan melalui pelaksanaan program madrasah, hal tersebut diperkuat oleh wawancara dengan bapak $\mathrm{H}$. Edeng Suapi, M.Pd.I, selaku kepala madrasah memberikan informasi mengenai penataran atau seminar yang diadakan oleh pengawas Madrasah Ibtidaiyah dari Seksi Pendidikan Madrasah Kementerian Agama Karawang.

Kedisiplinan dalam waktu diterapkan didalam madrasah, seperti guru harus sudah ada di madrasah sebelum murid sudah ada standar denda bagi guru yang lalai dalam bekerja. Dan bapak selalu mengadakan pembinaan termasuk hal kedisiplinan waktu pada saat pemberian honor kepada guru, itu sudah dalam persetujuan guru dan tenaga kependidikan. Pemberlakuan program reward dan punishment dalam peraturan kedisiplinan waktu untuk menghindari kelalaian guru contohnya telat datang ke madrasah. Jika guru yang telat ataupun lalai akan dikenakan denda lima ribu rupiah perhari dan jika ada guru yang memiliki mentaati peraturan maka ada penambahan gaji dan itu atas masukan dan persetujuan bersama dengan guru dan tenaga kependidikan

Berdasarkan hasil wawancara dan observasi menunjukan bahwa kepala MIS Asy Syarifiyah Kecamatan Cikampek Kabupaten Karawang melakukan sudah merencanakan program madrasah dalam peningkatan kinerja guru, baik internal (rapat bulanan madrasah, disiplin guru, program reward dan punishment) maupun eksternal (kegiatan penataran atau seminar dari Kementerian Agama Seksi Pendidikan Madrasah) dan pelaksanaan sesuai dengan perencanaan yang dibuat seperti rapat bulanan di madrasah, pembinaan pengawas Madrasah Ibtidaitah Karawang, kedisiplinan guru dan kemudian pemberlakuan program reward dan punishment), namun guru juga diikutsertakan dalam program lembaga pendidikan Islam tingkat kecamatan maupun tingkat kabupaten seperti penataran atau seminar.

\section{KESIMPULAN DAN SARAN}

Berdasarkan hasil dan pembahasan penelitian tentang peran kepemimpinan kepala madrasah dalam meningkatkan kinerja guru di MIS Asy Syarifiyah Kecamatan Cikampek Kabupaten Karawang, baik melalui wawancara, observasi, dan dokumentasi. Maka peneliti simpulkan Peran Kepemimpinan Kepala Madrasah Dalam Meningkatkan kinerja menggunakan gaya kepemimpinan demokratis, karena pembuatan keputusan akhir adalah kepala madrasah setelah menerima masukan dan rekomendasi atau keputusan bersama dengan guru maupun tenaga kependidikan. Sebelum melakukan perencanaan, kepala madrasah melakukan analisis pekerjaan dan analisis jabatan bagi guru dan tenaga kependidikan. Dengan analisis, kepala madrasah dapat menempatkan guru sesuai dengan kemampuan dalam 
meningkatkan kinerja guru meliputi perencanaan kepala madarsah yaitu membuat perencanaan program madrasah. Dan Pelaksanaan melalui pembinaan dan pengembangan guru, yaitu mengikuti penataran atau seminar bagi guru, Reward (Penghargaan) dan Punishment (Hukuman) dan disiplin guru madrasah. Dalam Hubungan gaya kepemimpinan kepala madrasah dan perencanaan maupun pelaksanaan kepala madarsah dalam meningkatkan kinerja guru berupa hubungan kausal yang bersifat sebab akibat yang mempengaruhi lima indikator peran kepemimpinan kepala madrasah dalam meningkatkan kinerja guru yang telah peneliti tanyakan kepada kepala madrasah dan guru telah melaksanakan lima indikator dengan baik sesuai dengan teori peningkatkan kinerja guru.

Berdasarkan penelitian yang dilakukan tentang peran kepemimpinan kepala madrasah dalam meningkatkan kinerja guru di MIS Asy Syarifiyah Kecamatan Cikampek Kabupaten Karawang. Adapun beberapa saran yang peneliti berikan dan bermanfaat diantaranya yaitu :

a) Bagi kepala madrasah MIS Asy Syarifiyah Kecamatan Cikampek Kabupaten Karawang:

- Untuk selalu mengusahakan penghargaan yang lebih spesifikasi atau khusus untuk para guru yang mentaati peraturan dan melaksanakan disiplin kerja agar guru termotivasi;

- Untuk terus mempertahankan dan meningkatkan kinerja guru melalui kedisiplinan untuk menjaga keprofesionalan guru di madrasah.

b) Bagi guru MIS Asy Syarifiyah Kecamatan Cikampek Kabupaten Karawang:

- Selalu menjadi guru yang professional dengan aktif dan kreatif dalam pembelajaran di madrasah;

- Selalu bersemangat dalam menjalankan tugas dan kewajiban sebagai guru.

\section{DAFTAR PUSTAKA}

Afifudidin, 2014, Kepemimpinan

Kepala Sekolah, Bandung, CV Pustaka Setia.

Pemerintah Indonesia, 2008,

Direktorat Jendral Guru dan

Tenaga Kependidikan

Nomor 4 dan 5 Tahun 2008

Tentang Peningkatan Mutu

Pendidik Dan Tenaga

Kependidikan.

H.E. Mulyasa, 2018, Menjadi Kepala

Sekolah Profesional, Bandung, PT Remaja
Rosdakarya.

H.E. Mulyasa, 2019, Manajemen \&

Kepemimpinan Kepala Sekolah, Jakarta, PT

Bumi Aksara.

Maulana Suryadilaga, Rendra,

Mochammad Al Musadieq dan

Gunawan Eko Nurtnahjono, 2016,

Pengaruh Reward dan Punishment

Terhadap Kinerja, Malang,

Fakultas Ilmu Administrasi

Universitas Brawijaya.

Susanto, Ahmad. 2016, Manajemen

Peningkatan Kinerja Guru,

Depok, Prenamedia

Group.Syukri, 2012, Peranan

Kepemimpinan Kepala Sekolah

Dalam Meningkatkan Kinerja

Guru Pada SMP Nurul Ihsan

Kabupaten Tolitoli Sulawesi

Tengah, Tolitoli.

Zazin, Nur. 2018, Dasar-Dasar

Manajemen Pendidikan Islam,

Malang, Ar-Ruzz Media. 